\title{
Linguo-Cognitive Nature of God Concept in B.-I. Antonych and J. Twardowski's Poetics
}

\author{
Veronika Chaikivska ${ }^{4}$ \\ ${ }^{1}$ Ternopil Volodymyr Hnatiuk National Pedagogical University, Ukraine \\ *Corresponding author.Email: g.bachynska@gmail.com
}

Halyna Bachynska ${ }^{1, *}$ Tetyana Vilchynska ${ }^{2}$ Oksana Werbowetska ${ }^{3}$

\begin{abstract}
The article is devoted to analyzing the linguo-cognitive nature of the concept of God in two national ethnolinguistic cultures - Ukrainian and Polish. The study is based on the best philosophical and religious texts represented by the works of B.-I. Antonych and J. Twardowski. Given the objective complexity and general lack of research on the whole set of problems associated with the analysis of religious poetry and the delineation of a new linguistic approach to its analysis, the topic of the article is relevant. The purpose of the investigation was to find out the peculiarities of the linguization of the concept of God in the Ukrainian and Polish linguistic and cultural traditions. The primary research method was conceptual analysis. The peculiarities of verbalization of the concept of God and its semantic-axiological nature in B.-I. Antonych and J. Twardowski's poetic texts were revealed in the course of the research. It is established that in the poetics of B.-I. Antonych nominative field of the studied concept includes significantly more names, among which there are many bright personal authorial paraphrases. As for the semantics, in both authors' works, the concept of God is used as a polysemantic, cognitive psycholinguistic phenomenon. For the most part, individual conceptual meanings in its structure are positively marked and evidenced by the numerous metrical feet. The study showed that the innovative pursuits of both writers in religious and philosophical poetry fit organically into the general aesthetic and ideological paradigm, in which in the twentieth century, not only European but also world culture developed. Comprehension of the concept of God inspired B.-I. Antonych and J. Twardowski with powerful energy, encouraging new ways of image creation, previously unknown in either Ukrainian or Polish religious poetry. The potential application of our research would be, on the one hand, in the further study of the sacred, and on the other - in the study of the other famous figures' language practices in different national cultures.
\end{abstract}

Keywords: concept, God, religious poetry, linguo-culture, verbalizer, semantic component, conceptual meaning, metrical feet, B.-I. Antonych, J. Twardowski.

\section{INTRODUCTION}

Religious and philosophical lyrics as the peak phenomenon of any national culture actualizes many research problems. The unity of poeticism and sacredness is the driving force that has contributed and continues to contribute to verbal art progress. The achievement of linguistic cognitology involves using effective methods of conceptual analysis of literary texts to identify the linguistic objectification features of the sacred in poetics, which belongs to the people's aesthetic and spiritual heritage. Thus, the topic of the proposed article is relevant in several aspects:
1. It intensifies scientific interests in the sacred, particularly in the Ukrainian ethnolinguistic tradition, which remains poorly studied due to atheism widespread in Soviet times.

2. It directs to the study of the sacred in the aspect of cognitive linguistics, where such works are still in deficit.

3. It actualizes the interest in different national cultures, namely the manifestation in them of the authors' religious and philosophical views as expressions of the mentality of their people. 


\section{METHODOLOGY}

The purpose of the research is to determine the linguistic and cultural nature and features of the linguistic explication of the concept of God in the Ukrainian and Polish ethnolinguistic traditions.

The object of analysis is the concept of God as a representative of the Christian worldview, the subject - the specifics of its verbalization and semanticaxiological characteristics in Bohdan-Ihor Antonych and Jan Twardowski's poetic world.

The research material was the best example of the twentieth century's religious and philosophical poetry of Ukrainian and Polish writers - B.-I. Antonych and J. Twardowski. We should note that in the first case, we used the book "Great Harmony" ("Velyka Harmonia") (2003) - one of the complete editions of poetic texts by B.-I. Antonych, in the second - book "Another Prayer" ("Insha Molytva") (2015) in the Ukrainian translation of Dzvinka Matiyash.

The main method used is conceptual analysis, which, according to V. Maslova, is the most optimal for the characterization of the concept because the use of specific methods, methodics, and research techniques depend not only on the complexity of the concept but also on the goals and objectives that a researcher has, as well as, on the research material [6]. Using this method, we determine the main means of verbalizing the concept of God and its semantic and axiological nature in the linguistic cultures of two Slavic nations - Ukrainian and Polish.

\section{RESULTS}

One should note that the work of B.-I. Antonych and J. Twardowski testifies to new horizons in national literatures; they changed the canons of Ukrainian and Polish religious poetry of the twentieth century forever. Their model of religious worldview provides a basis for their comparison. Attempts of this comparative analysis type were made by T. Golovan (J. Twardowski and V. Barka), Y. Grigorchuk (J. Twardowski and V. Vovk), and others. Implementation of the philosophical triad of God nature - man in the works of B.-I. Antonych and J. Twardowski, which is decisive for both artists' poetry, opens up limitless research opportunities.

When in the early 60's simultaneously with the poets of the sixties' debut, B.-I. Antonych's poems were published on the pages of Ukrainian periodicals; they impressed readers and critics. Trying to answer the question of what the magical gift of this Lemko poet is, researchers pointed to his entrenchedness in the Shevchenko tradition (D. Pavlychko), R. Tagor's lessons (M. Inytsky), echoes with the work of P. Tychyna (M. Zhulynsky), G. Lorca (I. Drach), V. Khlebnikov (B. Rubchak) and others, and tried to determine to which stylistic trend the author belongs. The writer is either accused of trying to stay aside from his nation's life or attracted to the camp of materialists, then focusing on his mythical outlook and then talking about him as an utterly sacred artist (Y. Zhulinsky, I. Drach). In general, as M. Ilnytsky remarked, "it was difficult to analyze the poems: the critical tools used in the analysis of the literary facts of the time did not work here [3]. Among other things, this is because B.-I. Antonych did not have any poems collection that contains more or fewer reflections on the various stages of gaining and understanding religious experience, from the child's naive faith to the spiritual integration of a person renewed with God. Experiencing the multiple periods of philosophical doubt and emotional pain, the poet is continually looking for inner balance in God. It is not crucial whether this is Christian God, before whom he bows or believes in, or the ancient God of cosmology responsible for nature, ensuring the world's existence, or other poeticized images of gods, the information about them is accumulated in the concept of God.

It is challenging to overestimate J. Twardowski's role in developing Polish religious poetry of the twentieth century. He entered the national literature primarily as a sacred poet (terminology from I. Betko's works) [2], all whose work - religious lyrics, pieces of religious content for children, preaching prose - is a constant dialogue with God, where the author asks, doubts, fears, loves. Although J. Twardowski's works were in the center of scientific interest (A. Bazylewski, O. Ivanovska, A. Kamenska, M. Strikha, and others), many aspects still require thorough study. To understand the writer better, penetrate into his world, and understand the relationship with the creator, an analysis of one of the main manifestations of the sacred in his religious, poetic texts - the concept of God should be performed. It is no wonder A. Kamenska, a researcher of his work, compares him to St. Francis, stating, "if St. Francis were a modern poet, he would write like Jan Twardowski"[9].

Although the concept phenomenon has become widespread in recent decades and has become a socalled "fashionable" object of study in the modern scientific paradigm, it is still interpreted differently. In the article, we use the definition of the Ukrainian researcher T. Kosmeda, who understands the concept as "multidimensional culturally significant sociopsychological formation in the cognitive 
consciousness, which is objectified in one or another language form" [5]. It is significantly supplemented with the definition of Belarusian linguist V. Maslova, which defines the concept "as a semantic formation, marked by linguistic and cultural specifics, which characterizes particular ethnoculture carriers accordingly. The concept, reflecting the ethnic outlook, marks the ethnic picture of the world..." [6].

As noted by another Ukrainian scholar V. Kononenko, the literary text application "provides an in-depth internal description of the concept, its, perhaps, hidden, subconscious or unconscious, archetypal foundations ... Moreover, if he is genuinely a folk ideals exponent, the writer conveys not only his ideas about the meaning of the concept but also ethno psychological, psycholinguistic foundations of nationwide understanding of conceptual ideas" [4].

As for the concept of God (gods), in the Slavic ethnic tradition, it is defined as the most significant power endowed with authority and opportunities and is considered as the highest sacred value [7].

The main verbalizers of the corresponding conceptualized ideas in both authors' works are lexemes Boh, Hospod, Khrystos (God, Lord, Christ). For example, "Bozhe, chy ty znash, yak nam viry treba... [1, p. 216]; Hospody, pomylui vid temnoty zoru [1, p. 232]; Shchonochi skarzhytsia roslynnym bolem teren, shcho / musiv vin kolys cholo Khrysta koloty [1, p. 127] and Ya shukav Boha u knyzhkakh... [8, p. 56]; - Hospody ya nedostoinyi / shchob do mene prykhodyly sny [8, p. 176]; Sumna liubov / sumnyi Khrystos iz holoiu spynoiu [8, p. 106]. In general, artistically comprehending the dogma of the Holy Trinity, B.-I. Antonych uses names to denote all three Persons of God, the Father, the Son, and the Holy Spirit, extensively. In addition to the mentioned lexemes, he uses such namings as Dukh, Holub-Dukh, Bozhe Dytia (Spirit, Dove-Spirit, God's Child), for example Spivai, dushe moia, mohutniu pisniu Bohu, I zlety na mene, Holub-Dukh, i krylamy zakryi [1, p. 233]; Na tykh saniakh v syn neznanu / Dytia Bozhe povezut [1, p. 104]. In J. Twardowski's poetry, the common name for the designation of God, which is obviously due to the greater faith of Poles in angelic power, is Anhel-Khoronytel (Guardian Angel), less often - Isus (Jesus), e.g. Anhele-Khoronyteliu khorony nashi hory / khai vony zavzhdy budut odnakovi [8, p. 168]; Yakym bude dvadtsiat pershe stolittia? / pytaiut pastushky shcho spivaiut na kolinakh / navit Isus takyi malenkyi shcho ne znaie [8, p. 196].

The original paraphrases belong to the common linguistic means of the God concept verbalization in the poetics of B.-I. Antonych. Their analysis shows that they are one of the favorite author's methods of creating a poetic image. The occasionality of paraphrases, like most tropes, is based on a double deformation; on the one hand, we observe norms violations in terms of the logic of existence, and on the other - emergence from the confines of linguistic elements deformation in the process of creating tropes in contemporary Ukrainian poetic speech. The following paraphrastic phrases are its brightest examples Velykyi Zhnets Dush, Maister osiainoi muzyky eteru, Pan tyshi y revu bur, nastroinyk dnia $i$ nochi Pan barvi zvukiv, zapakhu kvitok i shumu khvyl, naivyshcha Vlada Vlad, Tvorets sotni misiatsiv, miliona zir, and others. We should note that some of them depict the traditional Christian religious worldview ideas about God as a lord and creator, while others represent the author's pantheistic views. On the one hand, Bohdan-Ihor Antonych is inclined to think about the inseparable unity of the powerful natural forces with God, seeks to understand the concepts of temporality and immortality, the universality of man and the greatness of God (collection "Zelena Yevanheliia" ("Green Gospel")); on the other - he seeks mental balance in unity with Christian God, as if praying for his sins in front of him (the collection "Velyka Harmoniya" (“Great Harmony")).

Having ordained the priesthood in 1948, J. Twardowski appealed to the Christian God, who worships, to whom he prays. The author's respectful attitude is demonstrated by tautology as a stylistic means of enhancing emotionality, language expressiveness tilky huby samotni netsilovani / Boha dlia Boha [8, p. 157] or use bez Boha pryvede do Boha [8, p. 175], comparing with B.-I. Antonych ... bo ye naivyshcha Vlada Vlad, / shcho prysud izreche [8, p. 248].

It is known that the transition to Christianity was characterized by the fact that the pronouns Vin, Toi, Ty (He, That, You) in different cases were often used to name God. However, in the poetry of B.-I. Antonych the pronoun Vin is more productive - ta naibilshyi Vin sered ubohykh stin [1, p. 213] or Dlia Noho khochu hraty [1, p. 219]. In contrast, the pronoun Ty (You) is more emphasized, for example, Kudoiu do Tebe / chy tilky cherez ofitsiini vorota / za sviatymy shcho ydut $i$ ydut [8, p. 42] chy samotnosti ye rizni / na zemli u pekli na nebi / vsiliaki tilky odna / ta shcho vede do Tebe [8, p. 78].

In Antonych's poetic texts, also, the semantic content of pronouns is sometimes specified with the help of such nouns as Vin - harmoniia, Vin - akord muzychnyi, / Vin-kamerton... [1, p. 213]. 
In general, B.-I. Antonych uses significantly more verbalizers of the concept of God, including the names that are the result of the secondary nomination - krasa (beauty), liubov (love), potikha (fun), spiv (singing), svitlo (light), etc, - Ty pisnia sontsia i yasnoho dnia [1, p. 229] or Ty dlia vich vichne svitlo... / Ty liubov... / Ty potikha... [1, p. 229], and nouns (Prasvitlyi, Praiedynyi), e.g.: Prasvitlyi, Praiedynyi, shcho mene / $v$ sadu zhyttia velychnim posadyv $i$ hriiesh sontsem lasky! [1, p. 121].

J. Twardowski, referring to God, used variously structured phraseologized syntagms such as Sviatyi Bozhe, mylyi Bozhe, etc, tilky Bozhe mii mylyi shcho robyty $z$ vidchaiem / shcho tilky y plentaietsia vid sebe do sebe [8, p. 65] or Sviatyi Bozhe sviatyi kripkyi sviatyi usmikhnenyi / shcho sotvoryv papuhu vuzha $i$ smuhastu zebru... / usmikhnysia do mene [8, p. 7], in comparison with Antonych: ... mii druh naikrashchyi i mii voroh naizavziatishyi, Bozhe mylyi! [1, p. 131].

The names Yanhol (Angel) and Ahnts (Lamb), used by both authors in different meanings, including God's designation, also attract attention. For example, Vzhe dolonia Yanhola torknulas hordoho chola [1, p. 223] and Otche bezzakhysnykh / bezboronnyi Ahntsiu... / kudy zh meni yty yak ne do Tebe / po prostotu sertsia [8, p. 8]. B.-I. Antonych used also Bozhe Yahnia (God's Lamb) in his works - Ya klychu do Tebe shchodnia: / Bozhe Yahnia [1, p. 229].

To conclude, B.-I. Antonych uses significantly more names of the concept of God, some of which have not been the subject of our analysis. In particular, deifying nature, he appeals to the roslynnyi boh (god of plants); praising the beauty of the human body, he greets the badiori bronzovi bohy (vigorous bronze gods); the poet's rejection of urban life leads to the emergence of the mishchanskyi boh (bourgeois god).

Hence in his works, many other nominations, such as boh roslyn i zviriv (the god of plants and animals), the coral god (koralevyi boh), zelenyi boh (the green god), stolytsyi boh (the capital god) and others. In general, we state that religious education itself contributed to the particularly acute experience of the beauty of his native Lemkivshchyna and the threats that the poet associated with urbanization processes and forced him to seek answers to various controversial questions in Christianity.

As for J. Twardowski, he, although he tries to understand the revelation of God through nature, as a priest he has a dialogue with the Christian God, whose name is not important to him Boha mabut ne treba nazyvaty na imia / ne treba skladaty molytvy z nazv/ adzhe Boh nenazvanyi [8, p. 16].
The method of conceptual analysis, as noted, also allows us to clarify the semantic and axiological nature of the concept of God. According to T. Kosmeda, despite the ambiguity of the term, "with the help of this technique, the semantics and culture connection becomes obvious" [5].

The main verbalizers' characteristics of the studied concept indicate its polysemantic. He accumulated more conceptual meanings in the artistic picture of B.-I. Antonych's world than in the poetics of $\mathrm{J}$. Twardowski, which primarily depends on the ideological and thematic orientation of the Ukrainian writer's collections of poems.

According to B.-I. Antonych's works researchers, pagan and Christian life models were not synthesized in his works (M. Ilnytsky, M. Novikova); then in the concept semantics, we trace the meanings formed not only in the Christian but also in the pagan scenario, such as "Toi, shcho ye povelytelem stykhii" ("the One who is the lord of the elements") Tse Toi, shcho sontse zvilniuie vid nochi kryh, / ...shcho iz doloni kydaie vitry, /...shcho stvoriuie y vynyshchuie svity /... [1, p. 123].

Thus, a complex fragment in the semantics of the concept analyzed in both authors' poetics includes a common component "Toi, shcho vtiliuie" ("He who embodies") and various differential components, namely: "sviatist" ("holiness") - Pryidy, pryidy do mene, Holube Sviatyi [1, p. 206] i Sviatyi Bozhe sviatyi kripkyi sviatyi usmikhnenyi [8, p. 7]; „dobrotu”: Pro tebe, dobryi Bozhe, mriie kozhne liudske sertse [1, p. 232] $i$ ne vybachaisia / navishcho / dobrota nahoroda za smutok [8, p. 205]; ,velych $i$ vsemohutnist": Vin yedynyi Boh velychnyi [1, p. 233] ta Vsesvit Yoho ne okhopyt / a Vin vmistyvsia v yaslakh / Usemohutnii [8, p. 184]; "omnipresence, ubiquity" ("vseprysutnist, povsiudnist") ...v kozhnii nochi, v kozhnim dni - ye Vin / vsiudy, vsiudy ye - Velykyi ta Yedynyi [1, p. 213] i Vin / u sertsi shcho kalataie / u teplii oseni / u zabutti toho shcho bolilo / $u$ proshchenni hrikhiv /... naspravdi skriz [8, p. 16]; "eace and tranquility" (,spokii $i$ umyrotvorennia”) Chas zadzvenyt u trunu, / pryhorne Boh mene [1, p. 219] and Po dorozi do Boha vse yaknailipshe [8, p. 207] and others.

At the same time, this semantic component in J. Twardowski's poems unfolds such conceptual features as "postiinyi" ("permanent"), "malyi" ("small" (newborn)), "neskinchennyi" ("infinite"), as well as "doskonalyi" ("perfect"), "vilnodumnyi" ("free-thinking"), "liberalnyi" ("liberal") etc, e.g., i dai nam samoho Sebe / Ty shcho postiinyi i ne vpertyi [8, p. 35]; Hruden yalynka / tilky Boh ne soromytsia / 
shcho vin takyi malyi [8, p. 160]; Neporakhovani bdzhilky / vyvilhy dereva mokh / anhely i korivky / bo neskinchennyi Boh [8, p. 152]; Yakby my sami vyhadaly Tebe dlia sebe / Ty buv by zrozumilishyi $i$ hnuchkishyi / abo takyi doskonalyi shcho baiduzhyi / abo takyi liubliachyi shcho nedoskonalyi / vilnodumnyi i liberalnyi [8, p. 47]; serioznyi bo takyi mudryi shcho vmiie radity [8, p. 184].

Linguistic conceptualization of God's image in the poetic works of Ukrainian and Polish writers testifies to many other similar semantic components, inherent in the corresponding concept also in naive and scientific pictures of the world, such as "Toi, shcho stvoryv svit" ("the One who created the world"), Tvorche sotni misiatsiv, miliona zir, .../ promeniamy sontsia skhodyt Tvii spokiinyi zir [1, p. 219] and Ty shcho stvoryv / tsvirkuna... / busla... / kruka... / barana... / mabut tvorennia svitu shche ne zavershylos / bo shche tryvaie Tvii nezakinchenyi usmikh [8, p. 45]; "the one who cares (helps, protects)" ("Toi, shcho dbaie (dopomahaie, zakhyshchaie)" in the poetics of B.-I. Antonych about people and animals O Bozhe, berezhy v zaviiu i liudski, i zviriachi kubla [1, p. 181] or Koly klychesh pomochi-Vin ye, / koly shukaieshVin ye... [1, p. 213]; in J. Twardowski's works about faith: Bozhe zakhyshchai viru prostykh liudei $[8, \mathrm{p}$. 99].

Both authors reveal the conceptual meaning of "Toi, shcho obdarovuie" ("He who bestows") (in the poetry of B.-I. Antonych with happiness, joy, strength) Holube Sviatyi, / napovny sertse shchastiam yanholskoi povnoty [1, p. 206]; Ty nam znov do dushi radist lliesh, / dobryi Bozhe [1, p. 229]; O Bozhe, dai, shchob ya $v$ zmahanni / stoiav, mov skelia, proty ord [1, p. 209]; in the poems of J. Twardowski, first of all, with love Ne v liudyny a $v$ Boha slid prosyty liubovi [8, p. 138] or Chytaiemo: Boh tak poliubyv svit... / sebto ne tilky liudei [8, p. 126]; Tym chasom Toi shcho liubyt ide prosto $z$ neba $[8$, p. 122].

At the same time, consistently in both ethnocultures, as we see from the analyzed texts, the semantic component "the One who gives a sense of harmony" ("Toi, shcho daie vidchuttia harmonii) is realized, A sohodni ya... / pohodyvsia iz Bohom ta svitom / $i$ znaishov doskonalu harmoniiu v sertsi $[1, \mathrm{p}$. 220] or Ty akord kosmichnoi harmonii dovkola [1, p. 220] and liudskoi liubovi zupynka uboha / liubyty liudynu shchob pryity do Boha / ...bo taka doroha / naspravdi tse shchastia [8, p. 151].

Equally, in both writers' works, the conceptual meanings are depicted as "the One who deprived doubt" ("Toi, shcho pozbavliaie sumniviv), "the One you can talk to" ("z yakym mozhna pospilkuvatysia"), "the One who is waiting to be announced" ("obiavlennia yakoho chekaiut"), for example, Ty iz moho sertsia sumniviv burian ta khoptu vytny [1, p. 207]; ... yedynu, korotku khvylynu / hutoryty z Bohom ... sam na sam [1, p. 216]; Bozhe, nam Obiavlennia treba znovu, / nas sichut osinni sumnivu doshchi [1, p. 216] ta raptom Vin pryishov nespodivano / skazav: / choho ty mene shukaiesh / na mene chasom treba pochekaty [8, p. 56]; yakshcho pohano / to y Boh pevno pryide [8, p. 154]; do Boha z usim idesh ne ohliadaiuchys [8, p. 113]; a Boh obiavliaietsia / cherez nashu slabist [8, p. 204].

In general, the study showed that most of the identified meanings in the structure of the concept of God are positively marked. To a large extent, this is demonstrated by the following semantic components, which objectify the admiration for God, the desire to glorify him, etc., such as "the One they worship, they pray", ("Toi, yakomu pokloniaiutsia, moliatsia") Shchaslyva tsia liudyna, / yasna yii doroha: / naivno, mov dytyna, / molytsia do Boha! [1, p. 218] and Moliusia Bozhe shchob ya ne zatuliav nichoho... / shchob tilky Tebe todi bulo vydno [8, p. 68]; "the One who is glorified" ("yakoho proslavliaiut") Dlia Tebe ladanom horiat zhemchuzhni vivtari, / dlia Tebe splachuiut poety sliv natkhnennykh dan, / dlia Tebe biut u sribni struny vishchi husliari [1, p. 232]; "the before which shed tears of admiration" ("pered yakym prolyvaiut slozy zakhoplennia”) [8, p. 204].

Simultaneously, it is necessary to comprehend the analyzed concept in close connection with the lyrical hero, which allows, according to I. Betko, to trace the path of spiritual integration of the author himself [2]. It is important to note that the lyrical hero, which helps to understand God, is present in almost every verse of B.-I. Antonych and, somewhat less frequently, in the poems of J. Twardowski. In the works of the Ukrainian poet, he appears to be listening to God's music Slukhaimo velykoho kontsertu, yak uvecheri / na fortepiano svitu - klade doloni Boh [1, p. 207]; then an enchanted poet who writes his poems to the praise of God Teper na khvalu Bohu / skladaty prosti yamby [1, p. 217]; then an enlightened singer to the glory of God Spivai, dushe moia, prechystu pisniu Bohu [1, p. 333]; for the Polish author - primarily a restrained rider Shchob pyshuchy virshi ya ne vzyvav Imeni Hospoda namarno [8, p. 36], and the addressee in the correspondence Pyshu lysta do Tebe pobachyty ne mozhu [8, p. 79]. At the same time, the lyrical hero himself is a locus for God for both writers Koly khtos molytsia / Boh u nomu dykhaie [8, p. 100], U zholobi moioho sertsia / sohodni narodyvsia Boh [8, p. 209] and the addressee for him: Boh chytaie virshi do smerti 
zabuti [8, p. 132] and Dlia mene poetyku / skladaie sam Boh [1, p. 211].

Researchers of the sacred often emphasize the ambivalent nature of the concept of God. This nature is to some extent evidenced by the semantic components that connote information about God as a dangerous, formidable force capable of punishment, such as "the One to beware of" ("Toi, yakoho slid osterihatysia"), strashna, strashna tse rich zhyvym popasty v ruky Boha [1, p. 207] and khto vid Khrysta tikaie - vazhkyi khrest otrymaie [8, p. 115]. Such conceptual meanings include those in which often contradictory ideas about God such as "He who knows everything" ("Toi, shcho vse znaie") and "He who knows not everything" ("Toi, shcho znaie ne vse") are explained, first of all in the works of J. Twardowski, for example, Boh uzhe vse znaie navit sered nochi $[8$, p. 121]; Nikhto ne znaie bilshe nizh Ty [8, p. 172] and Narikaiut na Boha shcho Vin ne chuie ne znaie / shcho Yomu vse baiduzhe [8, p. 145].

The realization of the ethnic component in the semantic structure of the studied concept also attracts attention in Ukrainian and Polish writers' poetry. Thus, Antonych's God was born on a sleigh / in the Lemko town of Dukli (narodyvsia na saniakh / $v$ lemkivskim mistechku Dukli) [1, p. 104], the image of Lemkos in kresania enhances the ethnic color here. In J. Twardowski's works, we come across the following context proishov Khrystos / prostyi yak kostel lyshe z odniieiu malvoiu / obtrushenyi vid snihu i polskykh koliadok [8, p. 39], in which Christ is associated with the church and Polish carols.

Significant activity in the works of both authors is shown by the meanings realized through the verbalizers of the concept of God in the positions of the subject of comparison, less often - the object of comparison. For example, ...o pryidy, Vsesylnyi Tvorche, zlyn do nas, nemov rosa [1, p. 220] ("Boh, yak rosa" ("God is like dew")) and a Vin yak liudyna kozhen bil pryimaie [8, p. 145] ("God as man" ("Boh, yak liudyna")) or I sontse nam uslid / z khmar dyvytsia na svit, / nemov Khrystos v ikoni [1, p. 263] ("the sun is like Christ" ("sontse, yak Khrystos")). Let us note that similar meanings, as well as the corresponding verbalizers, are much more pronounced in the poetic texts of the Ukrainian writer, for whom God is both "good" ("dobro"), "beauty" ("krasa"), "joy" ("radist"), "musician" ("muzykant"), "Tuning fork" ("kamerton"), “chord" ("akord"), "astronomer" ("astronom"), "unattainable spire" ("nedosiazhnyi shpyl"), "perfect sound" ("doskonalyi zvuk"), and much more Vin - kamerton, shcho stroit sertse tvoie [1, p. 213] or Ty Dobro y Krasa [1, p. 220]; while for
J. Twardowski God is "love" ("lyubov"), it is "church" ("kostel"), and already quite unexpectedly, "cranberry" ("zhuravlyna"), raptom Vin pryishov nespodivano / yak zhuravlyna pislia pershykh moroziv $[8$, p. 56].

In general, through such nouns, the individualauthorial understanding of God is realized. If its comparisons with dew or love are perceived as traditional, then the conductor or cranberry is purely authorial.

Numerous tropical units testify to vivid examples of the individual-authorial concept of God in linguistic objectification. Thus, both writers differently poetize the traditional image of God's hands (palms) (Bozhykh ruk (dolon)), for example, ...bo slidiv Yoho dolon / povnyi tsilyi Vsesvit, povnyi kozhnyi atom [1, p. 206] and Proshu Tebe skhovai mene / u krykhitnomu zakapelku Tvoikh liudskykh ruk/vid zghrai formul [8, p. 32]. B.-I. Antonych often uses oxymorons, ...z usikh Sakhar / naistrashnishe palyt lask Tvoikh pozhar [1, p. 206] or Tysha - tse mova, yakoiu hovoryt do liudyny Boh [1, p. 237]; metaphors, which in his work often unfold into super-metaphors, or rather, create a "new separate reality" (O. Zilinsky), Pro Tebe more hraie osiainyi, palkyi psalom, / pro Tebe viter hromovi lunki pisni spiva, / pro Tebe liutyi burevii morskym khvyliuie dnom, / pro Tebe shepotom shovkovym shelestyt trava [1, p. 231]; symbols Sokyroiu khvalyv shchodnia tvii batko Boha [1, p. 171]. J. Twardowski also prefers metaphors shchob vriatuvaty nizhnist Boh vynaishov humor [8, p. 180] or skhovai mene u spokoi paradoksiv Tvoikh [8, p. 184]; in addition, he uses transformed phraseology ne rozumiie berezhenoho Boh ne berezhe [8, p. 122]; tautology Skilky shche ye sviatoho vilnoho mistsia ... / mizh tochnymy naukamy pro Boha $i$ Bohom [8, p. 33].

\section{CONCLUSIONS}

The general study showed that the concept of God is a positively labeled cognitive linguistic-mental unit, which demonstrates both a national and author's understanding of the concept, which corresponds to numerous tropical structures in which the components are the concept verbalizers.

The elimination of various negative factors, especially in Ukraine, which hampered the comprehensive study of religious concepts in the ethnic consciousness and the specifics of their lingualization, will contribute to their thorough analysis. We see the prospects of such research, on the one hand, in the further study of the sacred, and on the 
other - in the study of language practices of other famous figures in different national cultures.

\section{REFERENCES}

[1] B.-I. Antonych, Velyka harmoniia (Modernistychna poeziia XX st.) (Great Harmony (Modernist Poetry of the 20th Century)), Veselka, Kyiv, 2003.

[2] I. Betko, Ukrainska relihiino-filosofska poeziia. Etapy rozvytku (Ukrainian religious and philosophical poetry. Stages of development), Wydawnictwo Uniwersytetu Slaskiego, Katowice, 2003, pp. 2-208.

[3] M. Ilnytskyi, Osiahaiuchy fenomen Antonycha (Comprehending the phenomenon of Antonych), Varshavski ukrainoznavchi zapysky X (2000) 164-169.

[4] V. Kononenko, Kontsepty ukrainskoho dyskursu, (Concepts of Ukrainian discourse), Plai, KyivIvano-Frankivsk, 2004, p. 15.

[5] T. Kosmeda, N. Plotnikova, Linhvokontseptolohiia: mikrokontseptosfera SVIATKY v ukrainskomu movnomu prostori, (Linhvokontseptolohiia: microcontseptosphere SVIATKY in the Ukrainian language space), PAIS, Lviv, 2010, pp. 41-63.

[6] V. Maslova, Vvedenye v kohnytyvnuiu lynhvystyku, (Introduction to cognitive linguistics), Flynta, Nauka, Moskva, 2004, pp. $36-58$.

[7] Slavianskye drevnosty: etnolyhvystycheskyi slovar (Slavic antiquities: ethnolinguistic dictionary), vol. 1, Mezhdunarodnye otnosheniya, Moskva, 1995.

[8] Ya. Tvardovskyi, Insha molytva: vybrani virshi, (Another prayer: selected verses), A-BA-BAHA-LA-MA-HA, Kyiv, 2015.

[9] A. Kamieńska, Między gołębiem w słońcu a ornitologiem. O poezji Jana Twardowskiego, (Between a pigeon in the sun and an ornithologist. On the poetry of Jan Twardowski), Tygodnik Powszechny, Znaki ufności, Kraków, 1971 (10), pp. 2-3. 